DOI https://doi.org/10.18551/rjoas.2018-07.29

\title{
THE EFFECT OF ENVIRONMENTAL AWARENESS ON CONSUMER BEHAVIOR OF ECO-FRIENDLY PRODUCTS MEDIATED BY ECO-FRIENDLY ATTITUDE
}

\author{
Hidayati Mustikaningrum \\ Faculty of Economics and Business, University of August 17, 1945 Semarang, Indonesia \\ E-mail: mustika.mom@gmail.com \\ ORCID: 0000-0002-5930-3562
}

\begin{abstract}
Considering serious environmental issues that could endanger the environment, people are starting to realize and apply eco-friendly behavior by purchasing eco-friendly products. This research aimed to determine whether eco-friendly attitude mediated the effect of environmental awareness on consumer behavior of eco-friendly products in young housewives at the Faculty of Economics and Business, University of August 17, 1945 Semarang. The research sampling applied purposive sampling technique by distributing the questionnaires to 70 respondents of young housewives aged 21-35 years. The research findings indicated that: environmental awareness had positive and significant effect on consumer behavior of eco-friendly products; environmental awareness had negative and insignificant effect on eco-friendly attitude; eco-friendly attitude had positive and insignificant effect on consumer behavior of eco-friendly products; attitude was not proven to mediate the effect of environmental awareness on consumer behavior of eco-friendly products to young housewives of the students of the Faculty of Economics and Business, University of August 17, 1945 Semarang. It showed that high environmental awareness with the absence of positive eco-friendly attitude had been able to improve consumer behavior of eco-friendly products.
\end{abstract}

\section{KEY WORDS}

Eco-friendly product, environmental awareness, eco-friendly attitude, consumer behavior.

Considering serious environmental issues that could endanger the environment, such as illegal logging, water pollution due to industrial waste, air pollution in urban areas, and declining biodiversity quality, people are starting to realize and apply eco-friendly behavior by purchasing eco-friendly products (green products). Eco-friendly products are classified as new products created to overcome the existing global warming problems, as well as to anticipate further environmental damage. As a form of innovation, these eco-friendly products need a long time to socialize its benefits and be adopted by the public (Rogers 2003). Eco-friendly products are usually marked with eco-friendly labels attached to the products. The label is a sign that distinguishes the product from other products to help the consumers choose eco-friendly products which also serve as a tool for producers to inform the consumers that the products they produce are eco-friendly (Goleman, 2009).

Consumer demand for these eco-friendly products has encouraged the producers to change their business orientation by considering ecological aspects other than the economic aspects. Green marketing was carried out on a variety of marketing activities including product modifications, changes in the process, replacement of the packaging, even changes to the promotion. Green marketing is carried out by the company to meet the needs and desires of the consumers for eco-friendly products as well as corporate their responsibilities to the environment. Green marketing consists of a wide range of business activities which intends to satisfy customers' needs and wants, as well as diminish the negative impacts on the natural environment (Tiwari et al., 2011).

Besides the consumer behavior of eco-friendly products, the attention to the packaging is also important. Plastic has become a human need whose numbers of demand continue to increase. Plastic and Styrofoam are examples of packaging materials that are difficult to decompose and destroy naturally. It takes 1,000 to 5,000 years to decompose the plastic 
naturally and it takes 50 to 1,000 years to make the Styrofoam decay by itself (Firdaus et al., 2008) If the plastic and styrofoam packaging are still used in large quantities, the balance of the environmental ecosystem will be threatened.

The effectiveness of this eco-friendly product begins with the consumer's awareness of the existence and function of the product. Consumer awareness of a product is usually used as an indicator of success over the product performance. It is because after the consumer has awareness, then the consumer will try the product until finally decide whether or not they will become a permanent consumer. In addition, consumers focus not only on their purchasing decision-making processes but also on awareness of the specific dimensions and characteristics of the product (Kwan et al., 2004).

Karavasalis et al (2015) stated that although consumers do not always buy eco-friendly products, consumers tend to do eco-friendly purchasing decision. Eco-friendly consumer behavior is characterized through attitudes and actions to protect the environment (Ali, 2013). A person can be an environmentally consumer if he/she cares about the earth; those are the people whose consumption patterns in terms of food, clothing, and every need, are oriented to the environment. For examples, people carry their own shopping bags, do not use chemical cleaners at home, replace tissues with handkerchiefs, try to reduce the amount of personal waste produced each day by bringing their own food containers when buying food, turning on air conditioner only when necessary, selecting plant-based foods than food derived from animal sources.

The research findings of Liping $\mathrm{Fu}$ et al (2018) suggested that pro-environmental attitudes were not significantly related to private pro-environmental behavior. Arttachariya (2012) stated that environmental awareness and environmental attitudes have positive correlation with the purchase of green products. This research is required to be conducted because there are still contradictions of previous research findings on the effect of environmental awareness and attitude toward the consumer behavior of green product. In this research, the variable of eco-friendly attitude is the mediation variable.

Young housewives are the most age group of concern in developing countries including Indonesia. Therefore, young housewives are also the target market of eco-friendly products which are classified as new products. The main thing that becomes the benchmark of consumer behavior eco-friendly product is the creation of the needs of young housewives of eco-friendly products on the basis of the benefits that the products offer. Based on the above problem, a research is required to be carried out with the research question "does eco-friendly attitude mediate the effect of environmental awareness on consumer behavior of eco-friendly products on young housewives of the students of Faculty of Economics and Business, University of August 17, 1945 Semarang?".

\section{LITERATURE REVIEW}

American Marketing Association (AMA) stated that the green marketing approach is the marketing of products that are mainly focused on environmental safety; it incorporates business activities which consist of packaging modification, production process, and green advertising (Yazdanifard \& Mercy, 2011). Green marketing is also described as any promotional activity which highlights the environmental ethics as business fundamentals and it can perceive an advantage of switching consumer behavior towards a brand (Peattie \& Charter, 2003). Green marketing consists of a wide range of business activities which intends to satisfy customers' needs and wants, as well as diminish the negative impacts on the natural environment (Tiwari et al., 2011). Green marketing also refers to an organization that puts its efforts in to promoting, pricing, and distributing products with eco-concerns (Sarkar, 2012).

Eco-friendly products are products made from natural raw materials, processed naturally, and marketed in a sustainable way with the nature (Goleman 2009). The consumed products are expected to form an eco-friendly and fair consumer behavior. Ecofriendly products are definitely organic products whose raw materials are developed in organic standards. Organic standards are the standard by which raw materials used to make 
products are not sprayed with pesticides and do not use other chemical fertilizers (Sivertsen \& Sivertsen 2008). Typically, organic products claim that the products are safer to use compared to products that use chemicals and they do not cause side effects for the consumers. Green/ eco-friendly products can be obtained on various types of goods, such as foods, containers, electronics, and cosmetics.

Consumption of eco-friendly products should be accompanied by more-wisely use of plastic packaging or Styrofoam. Plastic bags and Styrofoam are two types of packaging that is widely consumed. Plastics that we use are synthetic polymers made from petroleum that cannot be degraded microorganisms in the environment (Firdaus et al., 2008). Another type of packaging that is commonly used is polystyrene or better known as Styrofoam. Polystyrene is an aromatic polymer made from aromatic monomer styrene that is liquid hydrocarbons produced from petroleum. The people usually use polystyrene or Styrofoam in the form of food packaging and disposable drinking place (Daniel 2009).

Boztepe (2012) emphasized that the green consumers would stop consuming any harmful product which may affect their health, involve torture of animals and cause damage to the environment during production process, disposal or use. Eco-friendly behavior is consumer behavior that applies the concept of eco-friendly in every consumer behavior. According to Jayanti et al. (2014), there are some actions that must be performed as one of the consumer eco-friendly behaviors that is known as 3R (Reduce, Reuse, and Recycle). Karavasalis et al. (2015) stated that although consumers do not always buy eco-friendly products, they tend to do eco-friendly purchasing decision.

Environmental awareness is defined as the formation of environmental sensitivity through the conscious perception of environmental problems by the individual, and by behaving accordingly, taking precautions to protect the environment (Coertjens et al., 2010). Expected from the individuals, who are aware of the environment and worry about the effect of the environmental problems on themselves, to give importance to the environment and behave accordingly in each of their activities while living, because behaviors of the individuals against the environment result from a reflection of their environmental awareness (Gadenne et al., 2009). Kumar (2015) made an effort to know how we can create awareness among consumers about green marketing and to probe consumer attitude towards ecofriendly/ green products. The research stressed that marketers need to emphasize on green marketing as consumers are ready to pay a premium price for the green products.

Low consumer environmental awareness also causes low purchasing intentions on green products (Albayrak et al., 2013). Previous research findings, conducted by Ishawini (2011), showed that the overall environmental awareness was related to purchasing green products. There were also some researchers claiming that environmental awareness had positive and significant effect on purchasing behavior of green products (Akehurst et al., 2012). However, on the other hand, there were also researchers who pointed out the opposite result, that environmental awareness was not able to improve purchasing behavior of green products (Bamberg, 2003).

Cherian \& Jacob (2012) studied consumer's attitude towards environment-friendly products. They presented a conceptual framework of green marketing and various ways in which different consumer attributes are related to the concept of green marketing. It was concluded that there is a need for green marketing and a need for a shift in consumer behavior and attitude towards an environmental friendly lifestyle. The researchers recommended exploring the factors that encourage consumers to cooperate with green marketing, that is, through green product usage. Attitude towards the environment is a consistent learned reaction given as approaching environment-related matters positively, not approaching them or remaining impartial to them (Flamm, 2009). According to Erten (2005), attitude towards the environment is formed from all the positive or negative behaviors and opinions of people towards the environment such as fear, anger, unease, and value judgment which result from environmental problems, and a preparedness for the solution of environmental problems. The company must know the consumer attitude in purchasing decision because one's attitude is the result of a psychological process, then it cannot be observed directly but must be concluded from what they say and do (Suprapti, 2010). 
Eco-friendly attitude is the psychological reaction to the environment shown by the individual and it affects individual's behavior (Chen, 2014). Eco-friendly attitude is generally associated with a person's level of interest to the environment. Eco-friendly attitude consists of several dimensions including: the importance of being eco-friendly, the inconvenience of being eco-friendly, serious environmental problems, and the level of company's responsibility (Jokom \& Kristanti, 2014).

Research related to environmental awareness and attitude has been conducted by Albayrak et al. (2013) which showed that environmental awareness had positive and significant effect on consumer attitude. The research findings of Liping Fu et al (2018) suggested that pro-environmental attitudes were not significantly related to private proenvironmental behavior. Arttachariya (2012) stated that environmental awareness and environmental attitude had positive correlation with the purchase of green products. Previous research conducted by Paladino \& Baggiere (2008) indicated that consumer attitude was able to mediate the correlation between environmental awareness and purchasing behavior of green products.

\section{METHODS OF RESEARCH}

Population and Samples. The population in this research was young housewives aged 21-35 years who at the time of the research were the students of the Faculty of Economics and Business, University of August 17, 1945 Semarang. The samples were 70 people based on the minimum sample size using Eq. (1).

$$
n=\frac{(Z 1 / 2 \alpha) 2(\delta) 2}{(\varepsilon)}
$$

With the level of error $(\alpha) 10 \%$, then $Z 1 / 2 \alpha=1.645$, and $(\varepsilon)=0.1$ standard deviation $(\delta)=0.5$. Therefore, the minimum sample $(n)$ was 67.65 rounded to 70 respondents.

Research Sampling and Data Collection. The research sampling used in this research was non-probability sampling technique. The type of the sampling was purposive sampling. Purposive sampling was a sampling technique based on certain considerations; the selected samples in the research were young housewives aged 21-35 years old. After the data were collected, the questionnaires were analyzed through its validity and reliability to get feasible data for the research.

Research Model and Hypothesis. The research model applied the paradigm of path analysis with 2 (two) regression equations consisting of simple linear regression and multiple linear regression using standardized coefficients consisting of: 1) $X 2=b 2 X 2+e$ and 2) $Y=b 1 X 1+b 2 X 2+e$. The research model could be described in the following Figure 1.

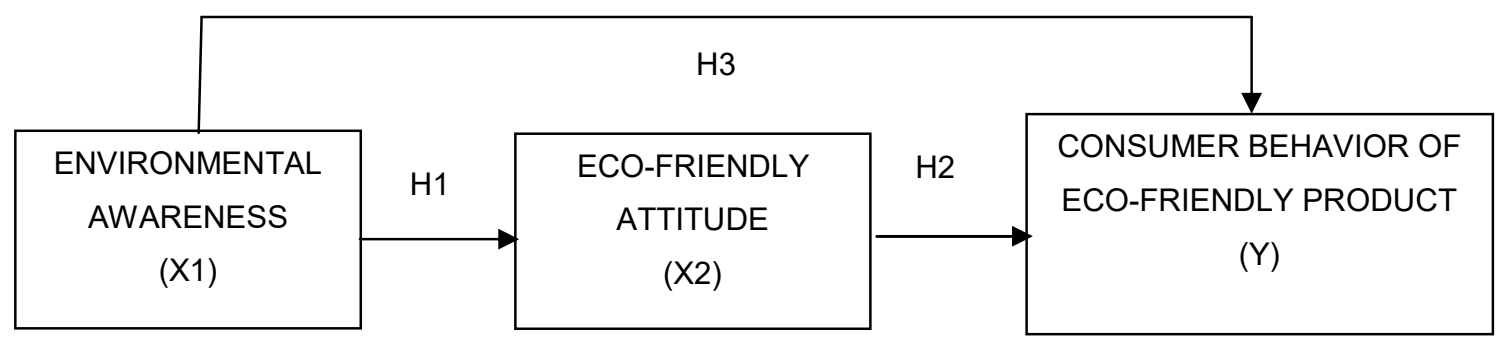

Figure 1 - Research Model

Research Hypothesis. Based on the research model, in Figure 1, there were 4 (four) hypotheses. The hypotheses were: 1) environmental awareness had positive and significant effect on eco-friendly attitude, 2) eco-friendly attitude had positive and significant effect on consumer behavior of eco-friendly products, 3) environmental awareness had positive and significant effect on consumer behavior of eco-friendly products, 4) eco-friendly attitude mediates the effect of environmental awareness on the consumer behavior of eco-friendly 
products to young housewives of the students of the Faculty of Economics and Business, University of August 17, 1945 Semarang.

Research Variables and Indicators. Research variables and indicators as well as the measurement scales were presented in the following Table 1.

Table 1 - Research Variables and Indicators

\begin{tabular}{|c|c|c|c|c|}
\hline No & Variables & Definition of the Concepts & Indicators & $\begin{array}{l}\text { Measurement } \\
\text { Scale }\end{array}$ \\
\hline 1 & $\begin{array}{l}\text { Environmental } \\
\text { Awareness (X1) }\end{array}$ & $\begin{array}{l}\text { Environmental awareness is defined } \\
\text { as the formation of environmental } \\
\text { sensitivity through the conscious } \\
\text { perception of environmental } \\
\text { problems by the individual, and by } \\
\text { behaving accordingly, taking } \\
\text { precautions to protect the } \\
\text { environment }\end{array}$ & $\begin{array}{l}\text { Positive attitude on eco-friendly } \\
\text { products and packaging } \\
\text { Making eco-friendly products a } \\
\text { primary preference for shopping } \\
\text { Starting to understand the aims of } \\
\text { eco-friendly products } \\
\text { Understanding the information of } \\
\text { eco-friendly products, plastic } \\
\text { packaging, and Styrofoam }\end{array}$ & $\begin{array}{l}\text { Likert scale } \\
1-5\end{array}$ \\
\hline 2 & $\begin{array}{l}\text { Eco-friendly } \\
\text { Attitude (X2) }\end{array}$ & $\begin{array}{l}\text { Eco-friendly attitude is the } \\
\text { psychological reaction to the } \\
\text { environment shown by the individual } \\
\text { and it affects the individual's } \\
\text { behavior }\end{array}$ & $\begin{array}{l}\text { The importance of being eco- } \\
\text { friendly } \\
\text { Serious environmental problems } \\
\text { The level of government } \\
\text { responsibilities }\end{array}$ & $\begin{array}{l}\text { Likert scale } \\
1-5\end{array}$ \\
\hline 3 & $\begin{array}{l}\text { Consumer } \\
\text { Behavior of Eco- } \\
\text { friendly Products } \\
\text { (Y) }\end{array}$ & $\begin{array}{l}\text { Green consumers would stop } \\
\text { consuming any harmful product } \\
\text { which may affect their health, } \\
\text { involves torture of animals and } \\
\text { causes damage to the environment } \\
\text { during production process, disposal } \\
\text { or use }\end{array}$ & $\begin{array}{l}\text { Consuming eco-friendly products } \\
\text { and packaging } \\
\text { Using plastic and Styrofoam } \\
\text { packaging wisely } \\
\text { Repurchasing eco-friendly } \\
\text { products } \\
\text { Recommending eco-friendly } \\
\text { products and packaging } \\
\text { Willing to pay with higher price }\end{array}$ & $\begin{array}{l}\text { Likert scale } \\
1-5\end{array}$ \\
\hline
\end{tabular}

Source: the developed theories and research journals.

Validity and Reliability Tests. In order to measure the validity test, questionnaire or indicator was considered to be valid, if $r$-calculate $>r$-table, that is comparing total item value - total correlation at the result of reliability test with result of $r$-table calculation. The reliability was tested with Cronbach's alpha ( $\alpha$ ) statistical test. A construct/ variable were considered to be reliable, if it gave the value of cronbach's alpha $(\alpha)>0.60$.

With the help of SPSS computer version 22 for windows, the validity test applied total item value - total correlation (sample/ $n=70$ and $\alpha=0.05$, $d f=n-2$, so r-critical $=0.1982$ ). It was found that all indicators had r-calculate larger than $r$-critical $(0.1982)$. Therefore, it could be said all indicators were valid. The reliability test of environmental awareness (X1) and eco-friendly attitude $(\mathrm{X} 2)$ with consumer behavior of eco-friendly product $(\mathrm{Y})$ were reliable because it had coefficient values above 0.6.

Normality Test and Classical Assumption Test. The regression model used must meet the following requirements: normality test (Kolmogorov-Simonov significance $>0.05$ ) and classical assumption test (heteroscedasticity test and multicollinearity test). Heteroscedasticity test (glacial test significance $>0.05$ ) and multicollinearity test (tolerance value of free variable $>0.1$ and VIP value of free variable $<10$ ).

Analysis Tool and Hypothesis Testing. Analysis technique of this research was path analysis. Path analysis was a technique used to analyze causal correlation that occurs by using multiple regressions if the independent variables affect the dependent variable not only directly but also indirectly (Ghozali, 2011).

Hypothesis 1, 2 \& 3 tests were conducted by using t-test (partial) whereas hypothesis 4 test was conducted by using path analysis test with mediation test (intervening test). Intervening test was conducted to determine whether the variable used was intervening variable or not. Thus, it could be explained based on the path diagram model (Ghozali, 2011). 


\section{RESULTS AND DISCUSSION}

The results of normality test and classical assumption test (heteroscedasticity test and multicollinearity test) had met the requirement of each test. Thus, a simple linear regression model as well as multiple linear regressions could be used for the path analysis model.

Table 2 - Regression Result of the Effect of Environmental Awareness on Eco-Friendly Attitude Coefficients $^{a}$

\begin{tabular}{|c|c|c|c|c|c|}
\hline \multirow{2}{*}{ Model } & \multicolumn{2}{|c|}{ Unstandardized Coefficients } & \multirow{2}{*}{$\begin{array}{l}\text { Standardized Coefficients } \\
\text { Beta }\end{array}$} & \multirow[b]{2}{*}{$\mathrm{t}$} & \multirow[b]{2}{*}{ Sig. } \\
\hline & B & Std. Error & & & \\
\hline $\begin{array}{l}1 \text { (Constant) } \\
\text { Awareness }\end{array}$ & $\begin{array}{l}12.045 \\
-.035\end{array}$ & $\begin{array}{l}2.086 \\
.123\end{array}$ & -.034 & $\begin{array}{l}5.773 \\
-.284\end{array}$ & $\begin{array}{l}.000 \\
.778\end{array}$ \\
\hline
\end{tabular}

a. Dependent Variable: Attitude

Based on the result of path analysis test (simple regression) in table 2, simple linear regression equation was $Y=-0.034 \mathrm{X} 1$ with Sig. value $t=0.778>0.05$. This meant that environmental awareness had a negative effect of -0.034 and was not significant to ecofriendly attitude. The conclusion was that hypothesis 1 was not proven.

Table 3 - Regression Result of the Effect of Environmental Awareness on Consumer Behavior of Eco-Friendly Products mediated by Eco-Friendly Attitude

Coefficients $^{a}$

\begin{tabular}{|c|c|c|c|c|c|}
\hline \multirow{2}{*}{ Model } & \multicolumn{2}{|c|}{ Unstandardized Coefficients } & \multirow{2}{*}{$\begin{array}{l}\text { Standardized Coefficients } \\
\text { Beta }\end{array}$} & \multirow{2}{*}{$\mathrm{t}$} & \multirow{2}{*}{ Sig. } \\
\hline & $\mathrm{B}$ & Std. Error & & & \\
\hline 1 (Constant) & 11.393 & 3.046 & & 3.740 & .000 \\
\hline Awareness & .405 & .147 & .316 & 2.757 & .008 \\
\hline Attitude & .203 & .145 & .160 & 1.400 & .166 \\
\hline
\end{tabular}

a. Dependent Variable: Behavior

Based on the results of path analysis (multiple regressions) in table 3 , multiple regression equation is $Y=0.316 \mathrm{X} 1+0.160 \mathrm{X} 2$ which indicated that:

- Eco-friendly attitude had positive value of 0.160 and the Sig. value $0.166>0.05$. It meant that eco-friendly attitude had positive and insignificant effect on consumer behavior of eco-friendly products. The conclusion was that the hypothesis 2 was not proven.

- Environmental awareness had positive value of 0.315 and the Sig. value $0.008<$ 0.05 . It meant that environmental awareness had positive and significant effect on consumer behavior of eco-friendly products. The conclusion was that hypothesis 3 was proved or accepted.

- Mediation Test. The mediation test was used to prove the eco-friendly attitude variable in mediating the effect of environmental awareness on the consumer behavior of eco-friendly products which could be illustrated in Figure 2.

$\mathrm{P} 3=0,316$

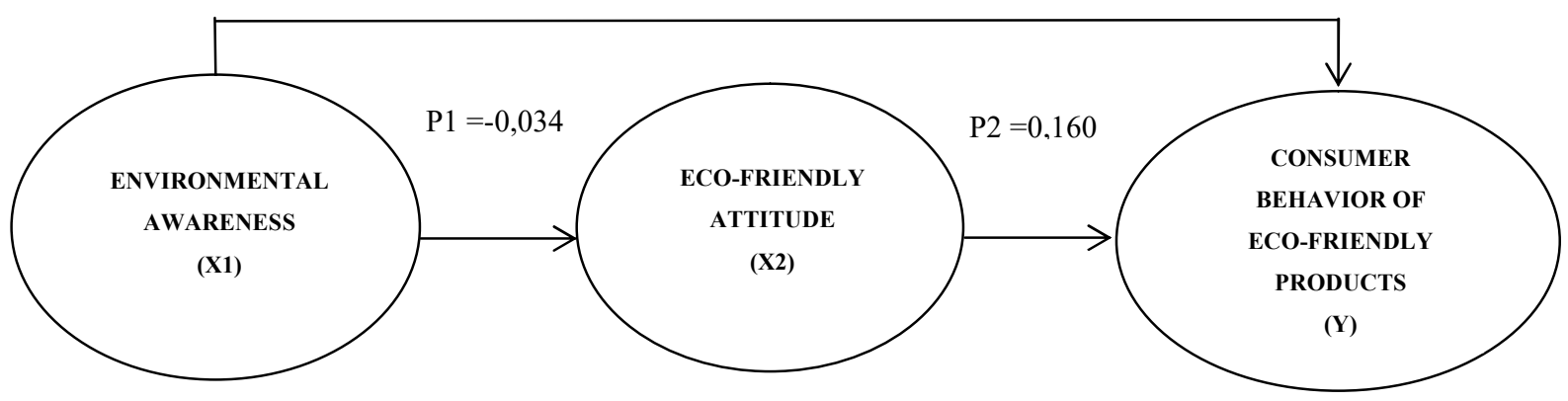

Figure 2 - Direct and Indirect Effects 
Tests of Direct and Indirect Effects. Based on the discussion of path analysis, the path coefficient could be explained in the model of the effect of environmental awareness on consumer behavior of eco-friendly products mediated by eco-friendly attitude in the following table:

Table 4 - Direct and Indirect Effects

\begin{tabular}{cccc}
\hline No & Direct Effect & Result & Formula \\
\hline Environmental awareness of \\
$\begin{array}{c}\text { consumer behavior of eco- } \\
\text { friendly products } \mathrm{X} 1 \rightarrow \mathrm{Y} 1=\mathrm{p} 3\end{array}$ & $\mathrm{p} 3=0.316$ & $\begin{array}{c}\text { Environmental awareness of consumer } \\
\text { behavior of eco-friendly products through } \\
\text { eco-friendly attitude } \mathrm{X} 1 \rightarrow \mathrm{X} 2 \rightarrow \mathrm{Y} 1=\mathrm{p} 1 \mathrm{p} 2\end{array}$ \\
\hline
\end{tabular}

Source: Processed Primary Data.

Based on the analysis results shown in Figures 2 and 4, it was known that the path coefficient on the indirect effect of environmental awareness on consumer behavior of ecofriendly product after being mediated by eco-friendly attitude variable was $-0.005<$ direct influence of environmental awareness on consumer behavior of eco-friendly products of 0.316 . Thus, eco-friendly attitude did not mediate the effect of environmental awareness on consumer behavior of eco-friendly products. The conclusion was that hypothesis 4 was not proven.

\section{DISCUSSION OF RESULTS}

The Effect of Environmental Awareness on Consumer Behavior of Eco-Friendly Products. The analysis result showed that environmental awareness had positive and significant effect on consumer behavior of eco-friendly products of 0,316 with sig. value $0.008<0.05$. It meant that the better the environmental awareness, the better consumer behavior. It was in accordance with the findings of previous research conducted by Ishawini (2011) which indicated that the overall environmental awareness was related to the purchase of green products. It was also in accordance with the findings of the research conducted by some researchers who stated that environmental awareness had positive and significant effect on the purchasing behavior of green products (Mostafa, 2007; Akehurst et al., 2012).

The Effect of Environmental Awareness on Eco-Friendly Attitude. The analysis result showed that environmental awareness had negative and insignificant effect on eco-friendly attitude of -0.034 with sig. value $0.778>0.05$. It meant that the better the environmental awareness would decrease eco-friendly attitudes even though the effect was less meaningful. It was not in accordance with research conducted by Albayrak et al. (2013) which showed the findings that environmental awareness had positive and significant effect on consumer attitude.

3. The Effect of Eco-Friendly Attitude on Consumer Behavior of Eco-Friendly Products

The analysis result showed that eco-friendly attitude had positive and insignificant effect on consumer behavior of eco-friendly products of 0.160 with sig. value $0.166>0.05$. It meant that the better the eco-friendly attitude, the better the consumer behavior of ecofriendly products although the effect was less meaningful. This was consistent with the research findings of Liping $\mathrm{Fu}$ et al (2018) who stated that pro-environmental attitudes were not significantly related to private pro-environmental behavior.

The Indirect Effect of Environmental Awareness on Consumer Behavior of Eco-Friendly Product mediated by Eco-Friendly Attitude. The analysis result showed that the indirect effect of environmental awareness on consumer behavior of eco-friendly product after being mediated by eco-friendly attitude variable was -0.005 < direct effect of environmental awareness on consumer behavior of eco-friendly product 0.316 . Thus, it could be concluded that eco-friendly attitude did not mediate the effect of environmental awareness on the consumer behavior of eco-friendly products. It showed that high environmental awareness with the absence of positive eco-friendly attitude had been able to improve the consumer behavior of eco-friendly products. 
These research findings were not in accordance with Arttachariya (2012) who stated that environmental awareness and environmental attitude had positive correlation with the purchase of green products. Previous research conducted by Paladino \& Baggiere (2008) showed the findings that consumer attitude was able to mediate the correlation between environmental awareness and purchasing behavior of green products. It meant that the effect of environmental awareness on the consumer behavior of eco-friendly products was not only driven by the positive attitude of eco-friendly but there were still other variables such as purchasing power. It was in accordance with the recommendations of the research conducted by Mustikaningrum Hidayati $(2016,2017)$ who stated that the effect of society awareness on eco-friendly products to the consumer behavior of eco-friendly products was mediated by socio-economic factors, namely income (ability of purchasing power), which was needed as the intervening variable that could improve the purchasing ability.

\section{CONCLUSION AND SUGGESTIONS}

Environmental awareness had positive and significant effect on consumer behavior of eco-friendly products to young housewives of the students of the Faculty of Economics and Business, University of August 17, 1945 Semarang.

Environmental awareness had negative and insignificant effect on eco-friendly attitudes to young housewives of the students of the Faculty of Economics and Business, University of August 17, 1945 Semarang.

Eco-friendly attitude had positive and insignificant effect on consumer behavior of ecofriendly products to young housewives of the students of the Faculty of Economics and Business, University of August 17, 1945 Semarang.

Attitude was not proven to mediate the effect of environmental awareness on consumer behavior of eco-friendly products to young housewives of the students of the Faculty of Economics and Business, University of August 17, 1945 Semarang.

It is necessary to conduct further research on purchasing power that mediates the effect of environmental awareness on the consumer behavior of eco-friendly products.

\section{REFERENCES}

1. Ali, S. (2013). Prediksi Perilaku Ramah Lingkungan yang dipengaruhi oleh Nilai dan Gaya Hidup Konsumen. Jurnal Perspektif Bisnis, 1(1), 112- 125.

2. Akehurst, G., Afonso, C., \& Goncalves, H. M. (2012). Re-examining green purchase behavior and the green consumer profile: New evidence. Management Decision, 50(5), 972-988.

3. Albayrak, T., Aksoy, S., \& Caber, M. (2013). The effect of environmental concern and scepticism on green purchase behavior. Marketing Intelligence \& Planning, 31(1), 27-39.

4. Arttachariya, P. (2012). Environmentalism and green purchasing behavior: A study on graduate students in Bangkok, Thailand. Retrieved from http://www.bu.ac.th/

5. Bamberg, S. (2003). How does environmental concern influence specific environmentally related behaviours? A new answer to an old question. Journal of Environmental Psychology, 23(1), 21-32.

6. Boztepe, A. (2012). Green Marketing and its impact on consumer buying behavior. European Journal of Economic and Political Studies, 5(1). Retrieved from http://ejeps.fatih.edu.tr/docs/articles/146.pdf

7. Chen, W. J. (2014). A comparative analysis of consumers' attitude and behavior toward green practices. Journal of Tourism \& Recreation, 1(2), 15-26.

8. Cherian, J., \& Jacob, J. (2012). Green marketing: A study of consumers' attitude towards environment friendly products. Asían Social Science, 8(12), 117-126

9. Coertjens, L., Pauw, J. B., Maeyer, S. D., \& Petegem, P. V. (2010). Do Schools Make a Difference in Their Students' Environmental Attitudes and Awareness Evidence From Pisa 2006. International Journal of Science and Mathematics Education, 8(3), 497-522.

10. Daniel, V.(2009). Easy Green Living. Jakarta: Penerbit Hikmah. 
11. Erten, S. (2005). Investigation of preservice preschool teachers' behaviors related to environmental awareness. Hacettepe University The Journal of Education, 28, 91-100.

12. Firdaus, F., Mulyaningsih, S., \& Anshor, H. (2008). Sintesis film kemasan ramah lingkungan dari komposit pati, khitosan, dan asam polilaktat dengan pemlastik gliserol. Logika, 5, 14-18.

13. Flamm, B. J. (2009). The impacts of environmental knowledge and attitudes on vehicle ownership and use. Transportation Research Part D: Transport and Environment, 14(4), 272-279

14. Ghozali, I. (2011). Aplikasi Analisis Multivariat dengan Program IBM SPSSv19. Semarang: Badan Penerbit UNDIP.

15. Gadenne, D.L., (2009). An Empirical Study of Environmental Awareness and Practices in SMEs. Journal of Business Ethics, 84 (1), 45-63.

16. Goleman, D. (2009). Ecological Intelligence. Jakarta: PT Gramedia Pustaka Utama.

17. Hidayati, M. (2016). Perilaku Konsumsi Produk Eco Friendly Berdasarkan Model AIDA (Attention, Interest, Desire, Action) Pada Masyarakat Semarang Dan Kendal Jawa Tengah.

18. Hidayati, M. (2017). The Application Of Aida Model (Attention, Interest, Desire, Action) On Consumption Behavior Of Eco-Friendly Product In Demak And Ungaran Of Central Java. RJOAS, 11(71), November 2017. DOI: https://doi.org/10.18551/rjoas.2017-11.09.

19. Ishawini. (2011). Pro-environmental concern influencing green buying: A study on Indian consumers. Management Science and Engine International Journal of Business and Management, 6(6), 124-133.

20. Jayanti, N. D., Kumadji, S., \& Yaningwati, F. (2014). Analisis faktor-faktor yang mempengaruhi green purchasing (survei pada pelanggan tupperware di kota malang).Administrasi Bisnis, 5, 63-69.

21. Jokom, R., \& Kristanti, M. (2014). Analisa perbedaan eco-friendly attitude dan ecofriendly intention antara turis lokal dan turis asing terhadap green hotel. Kinerja, 18, 130 140.

22. Karavasalis, G., Nerantzaki, D.-M., Pantelidis, P., Paschaloudis, D., \& Vrana, V. (2015). What generation $y$ in greece thinks about green hotels. World Journal of Entrepreneurship, Management and Sustainable Development, 11, 268-280.

23. Kumar, P. (2015). Green marketing products in India. DAV Academic Review, 1(1), 1-12.

24. Kwan, C.Y., Yeung, K.W., \& Au, K.F. (2004). Decision making behaviour toward casual wear buying: a study of young consumers in Maniland China. Journal of Management and World Business Research, 1, 1-10.

25. Liping Fu, Ye Zhang, Xiong Xiong, Yi n Bai (2018). Pro-Environmental Awareness and Behaviors on Campus: Evidence from Tianjin, China. EURASIA Journal of Mathematic, Science and Technology Education, 14(1), 427-445. DOI: 10.12973/ejmste/77953.

26. Peattie, K., \& Charter, M. (2003). Green marketing. In Baker, M. J (Eds.), The Marketing Book (pp. 726-755). Great Britain, UK: Butterworth-Heinemann.

27. Paladino, A. \& Baggiere, J. (2008). Are we "green"? An empirical investigation of renewable electricity consumption. European Advances in Consumer Research, 18, 340341.

28. Rogers, E.M. (2003). Diffusion of Innovations. 5th ed. New York: Free Press.

29. Sarkar, A. N. (2012). Green branding and eco-innovations for evolving a sustainable green marketing strategy. Asia-Pacific Journal of Management Research and Innovation, 8(1), 39-58. doi: 10.1177/2319510X1200800106

30. Suprapti, N. W. S. (2010). Perilaku Konsumen (Pemahaman Dasar dan Aplikasinya Dalam Strategi Pemasaran). Denpasar: Udayana University Press.

31. Tiwari, S., Tripathi, D. M., Srivastava, U., \& Yadav, P. K. (2011). Green marketing emerging imensions. Journal of Business Excellence, 2(1), 18-23. Retrieved from http://ezproxy.snhu.edu/login?url=http://search.proquest.com/docview/1010336807?acco untid=3783.

32. Yazdanifard, R., \& Mercy, I. E. (2011). The impact of green marketing on customer msatisfaction and environmental safety. Retrieved from http://www.researchgate.net/ 